\title{
Infectivity of Deinbollia mosaic virus, a novel weed-infecting begomovirus in East Africa
}

\author{
Martina Kyallo ${ }^{1}$ (D) Elijah Miinda Ateka ${ }^{2} \cdot$ Peter Sseruwagi $^{3} \cdot$ \\ José Trinidad Ascencio-Ibáñez ${ }^{4} \cdot$ Mildred-Ochwo Ssemakula $^{5} \cdot$ Robert Skilton $^{6}$. \\ Joseph Ndunguru ${ }^{3}$
}

Received: 27 May 2017 / Accepted: 9 July 2017 / Published online: 9 August 2017

(C) The Author(s) 2017. This article is an open access publication

\begin{abstract}
Weed-infecting begomoviruses play an important role in the epidemiology of crop diseases because they can potentially infect crops and contribute to the genetic diversity of crop-infecting begomoviruses. Despite the important epidemiological role that weed-infecting begomoviruses play, they remain insufficiently studied in Africa. Recently, we identified Deinbollia mosaic virus (DMV), a distinct begomovirus found naturally infecting the weed host Deinbollia borbonica (Sapindaceae) in Kenya and Tanzania. In this study, we investigated the capacity of DMV to infect a restricted host range of Solanaceae and Euphorbiaceae species. Biolistic inoculation of Nicotiana benthamiana with concatemeric DNAs resulted in systemic infection associated with yellow mosaic symptoms, while DNA partial dimers caused asymptomatic systemic infection. DMV was not infectious to cassava (Manihot esculenta Crantz), suggesting host resistance to the virus. Here, we demonstrate the
\end{abstract}

Martina Kyallo

m.kyalo@cgiar.org

1 Biosciences eastern and central Africa-International Livestock Research Institute (BecA-ILRI) Hub, P.O. Box 30709-00100, Nairobi, Kenya

2 Department of Horticulture, Jomo Kenyatta University of Agriculture and Technology, P.O. Box 62000-00200, Nairobi, Kenya

3 Mikocheni Agricultural Research Institute, P.O. Box 6226, Dar es Salaam, Tanzania

4 Department of Molecular and Structural Biochemistry, North Carolina State University, 132 Polk Hall, Raleigh, NC 27695, USA

5 School of Agricultural Sciences, Makerere University, P.O. Box 7062, Kampala, Uganda

6 International Centre of Insect Physiology and Ecology (icipe), P.O. Box 30772-00100, Nairobi, Kenya first experimental infectivity analysis of DMV in N. benthamiana and cassava.

\section{Introduction}

The family Geminiviridae is divided into nine genera based on genome organization and structure, host range, and insect vector namely Begomovirus, Mastrevirus, Curtovirus, Becurtovirus, Turncurtovirus, Eragrovirus, Grablovirus, Capulavirus, and Topocuvirus [1]. Begomovirus is the best described genus and includes emergent pathogens that are widely distributed worldwide and constantly threatening the cultivation of diverse economically important crops [2-4]. Begomoviruses are grouped as monopartite or bipartite depending on the number of genome components they possess. Bipartite begomoviruses have small circular, single-stranded DNA (ssDNA) molecules of about 2.5-2.7 kb known as DNA-A and DNA-B. Genes on DNA-A encode proteins involved in virus replication, gene expression, encapsidation, and vector transmission [5]. DNA-B codes for two proteins involved in virus movement between and within plant cells [6]. Monopartite begomoviruses have a single genomic DNA that is homologous to the DNA-A of the bipartite begomoviruses.

Begomoviruses are transmitted in a persistent and circulative manner to dicotyledonous plant species by the polyphagous whitefly Bemisia tabaci (Gennadius) (Hemiptera: Aleyrodidae). Begomoviruses are often associated with cultivated (crop) and non-cultivated (weed) plants. Weeds may act as natural hosts for many economically important plant viruses and can serve as sources of primary virus inoculum for whitefly transmission [7, 8]. Within the $B$. tabaci complex, the Middle East-Asia Minor 1 cryptic species (MEAM1, formerly B biotype) has been reported to 
colonize plants belonging to diverse botanical families and may be responsible for the horizontal transfer of begomoviruses between crop and weed plants [9, 10]. Weed-infecting begomoviruses act as progenitors of crop-infecting begomoviruses and contribute to their diversity via genetic recombination $[11,12]$. Despite the important role these weedinfecting begomoviruses play in crop diseases, they remain insufficiently studied in Africa.

Deinbollia mosaic virus (DMV) is a phylogenetically conserved bipartite begomovirus that was recently found infecting soapberry (Deinbollia borbonica), a non-cultivated plant species in the family Sapindaceae, which occurs in the coastal areas of Kenya and Tanzania [13]. Infected plants exhibit typical yellow mosaic symptoms and stunting. The plant host range of DMV has not been determined but may be limited to $D$. borbonica, the only known natural host. The economic importance of DMV has not been established yet. In this paper, we report the infectivity of DMV in plants belonging to the families Solanaceae and Euphorbiaceae.

\section{Materials and methods}

\section{Virus source and DNA extraction}

Leaf samples were collected from $D$. borbonica seedlings exhibiting yellow mosaic symptoms from a cassava field in northeastern Tanzania (GPS coordinates 05.10219S, 38.47172E; altitude, $202 \mathrm{~m}$; March 2015). The presence of whiteflies on the plants was noted. Total DNA was extracted using the protocol of the ZR Plant/Seed DNA MiniPrep kit (Zymo Research Corp.) according to the manufacturer's instructions.

\section{Virus amplification and cloning}

Full-length viral genomes were amplified from extracted DNA samples by rolling-circle amplification (RCA) with Q29 DNA polymerase (Illustra TempliPhi Amplification Kit, GE Healthcare) as per the manufacturer's instructions. The concatemeric DNAs were used directly for biolistic inoculation.

The full-length DNA-A (GenBank accession no. KT878824) and DNA-B (GenBank accession no. KT878825) (Fig. 1A and B) were amplified from total DNA using Phusion High-Fidelity DNA Polymerase (Thermo Fisher Scientific) and partially overlapping abutting primers DNA-A F $_{\mathrm{F}}\left(5^{\prime}\right.$-ATAGGATCCTTTAGT TAATGAGTTTCCTGAC-3') and DNA-A ${ }_{R}\left(5^{\prime}\right.$ - ATAGGA TCCCACATATTGCTACGCGTC-3') containing a natural BamHI restriction site (underlined), and primers DNA$\mathrm{B}_{\mathrm{F}}\left(5^{\prime}\right.$-CCCTCTAGAGAGAGAAGCT-3') and DNA-B ${ }_{\mathrm{R}}$

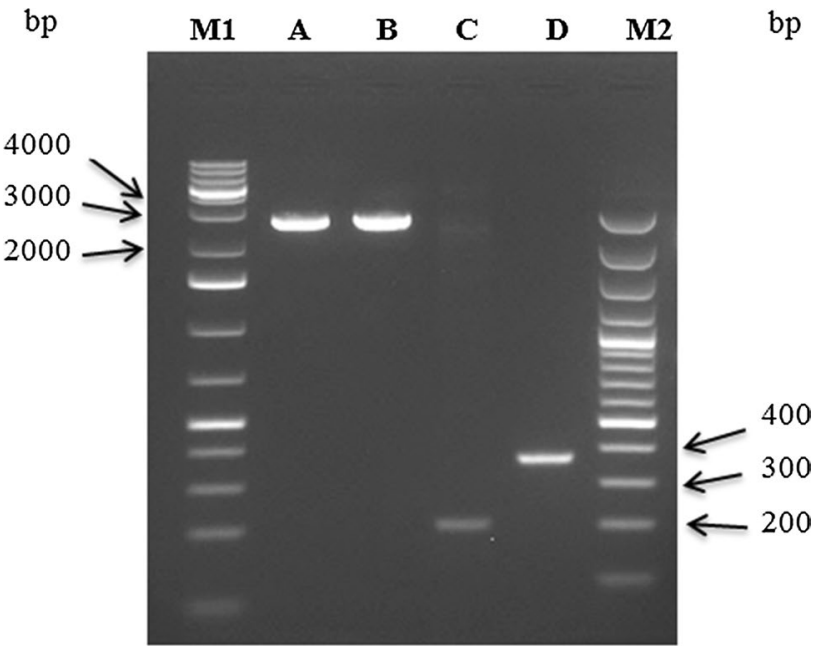

Fig. 1 Amplification of DMV genomic components from naturally infected Deinbollia borbonica. Full-length DNA-A (1), full-length DNA-B, (2), CRA (3), and CRB (4). The DNA rulers used are $1 \mathrm{~kb}+$ ladder (M1), and $100 \mathrm{bp}$ ladder (M2)

(5'-CCCTCTAGAATCCTCATCGTCG-3'), containing a natural XbaI site (underlined). Apparent full-length PCR products were cloned into the pUC18 vector (Fermentas, USA), resulting in the plasmids pDMVA-1.0 and pDMVB-1.0.

The Common Region (CR) of DNA-A (CRA) and DNA-B (CRB) was amplified with CRA and CRB primer pairs designed containing natural EcoRI, BamHI, and XbaI restriction sites (Table 1; Fig. 1C and D). To construct a partial repeat of DNA-A, a 0.4-mer $(1,111 \mathrm{bp})$ EcoRI/BamHI fragment of CRA was inserted into the unique EcoRI and BamHI restriction sites of pUC18, and the resulting clone was designated pDMVA-0.4. The fulllength BamHI/BamHI DMV-A fragment (2,852 bp) was digested from pDMVA-1.0 and inserted into the unique BamHI restriction site of pDMVA-0.4. The resulting clone containing 1.4 copies of DMV DNA-A was designated as pDMVA-1.4. A tandemly arranged partial repeat of DNA-B was constructed by inserting a 0.08 -mer (209 bp) $\mathrm{KpnI} / \mathrm{XbaI}$ fragment of CRB into the unique $\mathrm{KpnI}$ and XbaI restriction sites of pUC18, generating pDMVB-0.08. Insertion of the full-length XbaI/XbaI DNA-B fragment $(2,702 \mathrm{bp})$ from pDMVB-1.0 into the unique XbaI restriction site of pDMVB-0.08 resulted in a clone harbouring 1.08 copies of DMV DNA-B and was designated pDMVB1.08. The recombinant plasmids were introduced into Escherichia coli (DH5 $\alpha$ ) using the heat-shock transformation protocol. The orientation of the inserts was confirmed by restriction digestion (Fig. 2). 
Table 1 Primers used for Deinbollia mosaic virus (DMV) amplification

\begin{tabular}{llll}
\hline Primer & Sequence $\left(5^{\prime} \rightarrow 3^{\prime}\right)$ & $\mathrm{T}_{\mathrm{a}}\left({ }^{\circ} \mathrm{C}\right)$ & Reference \\
\hline $\mathrm{CRA}_{\mathrm{R}}{ }^{1, \mathrm{a}}$ & ATAGGATCCCACATATTGCTACGCGTC & 60 & This study \\
$\mathrm{CRA}_{\mathrm{F}}{ }^{1, \mathrm{~b}}$ & CCCCCATGAATTCTTTAAAATGCTTTAG & 60 & This study \\
$\mathrm{CRB}_{\mathrm{F}}{ }^{2, \mathrm{c}}$ & CCCTCTAGAGAGAGAAGCT & 60 & This study \\
$\mathrm{CRB}_{\mathrm{R}}{ }^{2, \mathrm{~d}}$ & TGGTACCAATAGCCTCCAAAAGCACGCA & 60 & This study \\
$\mathrm{B}^{2} / \mathrm{F}^{2}$ & TTGGCTCTCAGGTGTCCACGT & 63 & {$[13]$} \\
$\mathrm{B}^{2} / \mathrm{R}^{2}$ & ACGACCTCCATTACCTTCAACA & 63 & {$[13]$} \\
\hline
\end{tabular}

${ }^{1}$ Primer pair used for the PCR amplification of DNA-A fragments

${ }^{2}$ Primer pair used for the PCR amplification of DNA-B fragments

${ }^{\text {a }} \underline{\text { GGATCC }}=$ BamHI restriction site

${ }^{\mathrm{b}}$ GAATTC $=$ EcoRI restriction site

${ }^{\mathrm{c}}$ TCTAGA $=$ XbaI restriction site

${ }^{\mathrm{d}} \underline{\text { GGTACC }}=\mathrm{KpnI}$ restriction site

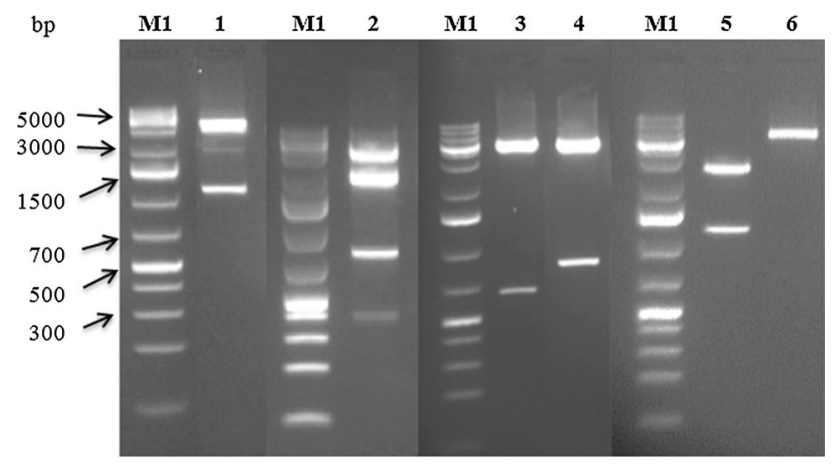

Fig. 2 Restriction digestion of DMV DNA partial dimers used for biolistic inoculation. Selected restriction enzymes were used to verify the orientation of PCR fragments of DMV cloned into pUC18: BamHI/EcoRI-pDMVA-1.4 (1), BgIII-pDMVA-1.4 (2), EcoRV-pDMVA-1.4 (3), EcoRV-pDMVB-1.08 (4), BamHI/EcoRIpDMVB-1.08 (5), and KpnI-pDMVB-1.08 (6). The DNA ruler used is $1 \mathrm{~kb}+$ ladder (M1)

\section{Inoculation of plants by sap and biolistic inoculation}

Nicotiana benthamiana was grown from seed, while cassava (Manihot esculenta Crantz) genotypes KME 1 and Mucericeri (which are highly susceptible to cassava mosaic disease [CMD]) were grown from virus-free stem cuttings obtained from Jomo Kenyatta University of Agriculture and Technology (JKUAT). To test the infectivity of DMV, virus-free test plants at the second- or third-true-leaf stage were inoculated by mechanically rubbing with homogenized plant sap and by biolistic delivery, with each experiment replicated three times.

Mechanical sap inoculation was carried out using inoculum derived from plants infected using concatemeric DNAs. Approximately $1 \mathrm{~g}$ of leaf tissue was ground with $0.2 \mathrm{mg}$ of carborundum ( 300 mesh) in $500 \mu \mathrm{L}$ of $0.2 \mathrm{M}$ sodium phosphate buffer ( $\mathrm{pH} 7.5)$ and used to inoculate the second set of true leaves of 10 plants of each test plant species. The inoculated plants were observed for symptom development until 35 dpi.

Concatemeric DNAs and DNA partial dimers were biolistically inoculated onto the meristem tissue using a hand-held particle acceleration device (Microdrop Sprayer II, Ascefran LLC, Raleigh, USA) at a pressure of 60 pounds per square inch (psi). For each experimental replicate, 10 test plants per plant species were inoculated with viral DNA, while two plants (negative controls) were inoculated with tungsten microprojectiles in water. Five $\mu \mathrm{g}$ of concatemeric DNAs or $2.5 \mu \mathrm{g}$ of partial dimeric DNA clones of each genomic component was mixed with $50 \mu \mathrm{L}$ of prepared $1.0-\mu \mathrm{m}$ tungsten particles (BioRad, Hercules, CA). Aliquots of $10 \mu \mathrm{L}$ per plant were used for bombardment in each experiment. Inoculated plants were kept in an environmentally controlled, insect-free growth chamber $\left(25^{\circ} \mathrm{C}, 65 \%\right.$ humidity and $16 / 8$ $\mathrm{h}$ photoperiod) and monitored periodically for symptom development, beginning 14 days post-inoculation (dpi) and monitored daily for approximately 35 days. The progeny virus from the bombarded plants showing symptoms was inoculated back to $N$. benthamiana biolistically to satisfy Koch's postulates for begomoviruses.

\section{Viral DNA detection by PCR amplification}

To confirm infection in test plants between 14 and $21 \mathrm{dpi}$, apical leaves from inoculated plants were harvested for virus testing by PCR analysis. The DMV DNA-A common region (CRA) was amplified using the primer pair CRA/F (5'-TGT TGACAGGTGTTTGTTTTGC-3') and CRA/R (5'-ATC ACGAATTAGATCATGGCCC-3'). PCR amplification was performed in a total volume of $20 \mu \mathrm{L}$ containing AccuPower PCR PreMix with dye (Bioneer, Korea), $0.1 \mu \mathrm{M}$ each primer, and $40 \mathrm{ng}$ of template DNA. Amplification was performed in a GeneAmp PCR System 9700 thermocycler (Applied Biosystems, Foster City, CA) using the following PCR program: an initial denaturation step at $94^{\circ} \mathrm{C}$ for $3 \mathrm{~min}$; followed by 35 
cycles of denaturation at $94^{\circ} \mathrm{C}$ for $30 \mathrm{~s}$, annealing at $60^{\circ} \mathrm{C}$ for $1 \mathrm{~min}$, and extension at $72^{\circ} \mathrm{C}$ for $1 \mathrm{~min}$; and then a final extension step at $72^{\circ} \mathrm{C}$ for $10 \mathrm{~min}$. The PCR products were analyzed in a $2 \%$ agarose gel stained with $0.025 \mathrm{X}$ GelRed (Biotium, USA).

\section{DNA probe labeling, hybridization and colorimetric detection}

A non-radioactive, digoxigenin (DIG)-labeled probe was synthesized by PCR amplification using the primer pair $\mathrm{B} 4 / \mathrm{F}$ and B4/R (Table 1), flanking the common region and nuclear shuttle protein gene (NSP), and pDMVB-1.0 according to the protocol of the digoxigenin (DIG) DNA Labeling and Detection kit (Roche Diagnostics, Indiana, USA). The reaction consisted of a denaturation step of $3 \mathrm{~min}$ at $94^{\circ} \mathrm{C}$, 30 cycles of $30 \mathrm{~s}$ at $94^{\circ} \mathrm{C}, 1 \mathrm{~min}$ at $63^{\circ} \mathrm{C}$ and $1 \mathrm{~min}$ at $72^{\circ} \mathrm{C}$, and a final extension step of $7 \mathrm{~min}$ at $72^{\circ} \mathrm{C}$. The PCR products were analyzed in a $1.8 \%$ agarose gel. The probe was denatured at $95^{\circ} \mathrm{C}$ for $10 \mathrm{~min}$ and snap-chilled in cold water for $5 \mathrm{~min}$ to prevent re-annealing.

Total DNA $(10 \mu \mathrm{L})$ for dot blot hybridization was obtained from each sample, denatured by heating for $5 \mathrm{~min}$ at $100^{\circ} \mathrm{C}$ in a water bath, and snap-chilled in ice water before blotted onto the nitrocellulose membrane (Hybond-N+, Amersham, UK). In tissue blot hybridization, fine crosssections of leaf petioles were hand cut with a surgical blade and gently pressed with a roller onto the nitrocellulose membrane. Then, the membrane was air-dried, and the DNA was cross-linked to the membrane through exposure to ultraviolet light for $1 \mathrm{~min}$ in a Stratalinker UV Crosslinker (Stratagene, USA) at 120,000 microjoules. Pre-hybridization and hybridization steps were carried out at $42^{\circ} \mathrm{C}$ in a hybridization oven (Amersham Biosciences, UK) in DIG Easy Hyb Granules (Roche Diagnostics, Indiana, USA) as per the manufacturer's protocol. The subsequent step of detection was done following the protocol of the DIG Nucleic Acid Detection
Kit (Roche Diagnostics, Indiana, USA). Colorimetric-based detection was done using 5-bromo-4-chloro-3-indolyl phosphate (BCIP) and nitroblue tetrazolium salt (NBT), which produced a purple color on regions on the nitrocellulose membrane containing viral DNA.

\section{Results}

\section{Infectivity and detection of DMV in $N$. benthamiana test plants}

Sap and biolistically inoculated $N$. benthamiana with DNA partial dimers of either DNA-A or DNA-B failed to establish infection with DMV. On the other hand, biolistic inoculation of a combination of DNA partial dimers of DNA-A and DNA-B onto $N$. benthamiana caused $100 \%$ infection (30/30), with test plants exhibiting two types of symptom phenotypes: symptomatic infection (using concatemeric DNAs) and asymptomatic infection (using DNA partial dimers). The first symptom of infection appeared $21 \mathrm{dpi}$ as yellow mosaic on the newly emerged leaves. At approximately $28 \mathrm{dpi}$, symptomatic plants exhibited some leaf yellowing and stunted growth with reduced leaf size relative to uninfected plants (Fig. 3). Some infected plants (50\%, $15 / 30$ plants) displayed a recovery phenotype, where symptom remission was observed but viral DNA was detectable by PCR, and dot blot analysis in young emerging leaves. All plants inoculated with DNA partial dimers were asymptomatically infected even after $35 \mathrm{dpi}$.

DMV was detected in infected $N$. benthamiana plants as a purple signal, while uninfected plants did not produce any signal in dot and tissue blot hybridization assays (Fig. 4A and C). PCR amplification of DNA-B from newly emerged uninoculated apical leaves of infected $N$. benthamiana plants using primer pair B4 (Table 1) resulted in a 450-bp amplicon (Fig. 4B), confirming the presence of the virus. PCR

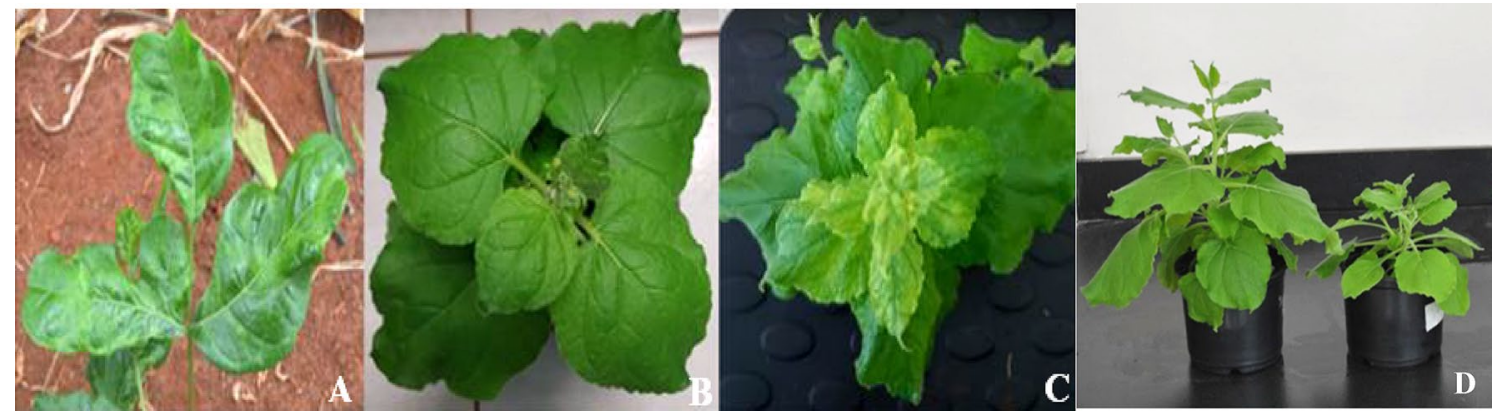

Fig. 3 Symptoms exhibited by $D$. borbonica and $N$. benthamiana plants infected with DMV. Field-collected $D$. borbonica showing yellow mosaic symptoms (A), mock-inoculated $N$. benthamiana (B), $N$. benthamiana inoculated with DMV concatemeric DNAs exhibiting yellow mosaic symptoms at $21 \mathrm{dpi}(\mathrm{C}), N$. benthamiana infected with DMV concatemeric DNAs showing stunting at approximately 28 dpi (D) 


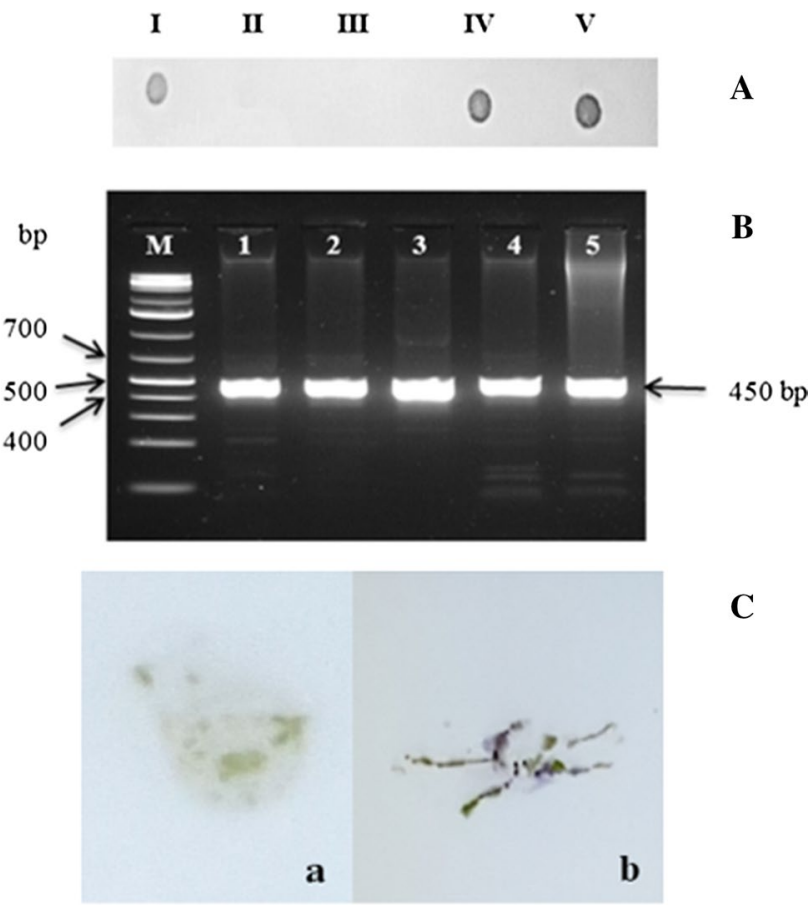

Fig. 4 Detection of DMV by hybridization and PCR amplification. The presence of DMV was confirmed by the presence of a deep purple signal on the nitrocellulose membrane in dot and tissue blot hybridization assays and by the amplification of a 450-bp PCR product using the B4/F and B4/R primer pair. The detection signals shown are from a $D$. borbonica infected with wild-type virus (A I, and B 1), healthy $D$. borbonica (A II), mock-inoculated $N$. benthamiana (A III, and $\mathrm{C}$ a), $N$. benthamiana inoculated with DNA partial dimers (A IV, B 2, and B 3), and N. benthamiana inoculated with concatemeric DNAs (A V, B 4, B 5, and C b)

amplification and Sanger sequencing confirmed the presence of DNA-A and DNA-B in newly emerged uninoculated apical leaves of infected test plants using overlapping PCR primers as described by Kyallo et al. [13]. Viral DNA was not detected in mock-inoculated test plant controls.

\section{Infectivity of DMV in cassava test plants}

None of the biolistically inoculated cassava test plants developed symptoms in any of the three replicated experiments using sap from infected $N$. benthamiana plants, concatemeric DNAs, and DNA partial dimers. The mock-inoculated test plant controls did not exhibit any signs of infection or demonstrate any hypersensitivity reaction (HR) in the infectivity assay (Fig. 5A and B). However, necrosis was observed only on leaves that developed immediately after the point of inoculation on the meristem of virus-inoculated plants, and the leaf margins become misshaped and deformed (Fig. 5C and D). Viral DNA-A and DNA-B was not detected in the newly emerged leaves by PCR amplification and hybridization analysis. No symptoms were observed up to $35 \mathrm{dpi}$.

\section{Discussion}

Biolistic inoculation to determine the infectivity of DMV was successful in $N$. benthamiana. Using concatemeric DNAs, systemic symptoms similar to those observed on infected $D$. borbonica in the field exhibiting yellow mosaic symptoms were induced. Also, the failure to cause infection using the sap inoculation method suggested that DMV was probably phloem-limited in infected plants.

Despite several attempts, we were unsuccessful in inducing infection in cassava and $N$. benthamiana using DNA partial dimers of single genomic components. The asymptomatic systemic infection exhibited by $N$. benthamiana plants inoculated with DNA partial dimers suggested that more-complex interactions existed between the natural host and the virus. Although we were unable to fulfill Koch's postulates with the cloned components of DMV, we were able to demonstrate that DMV concatemeric DNAs were infectious after re-introduction through biolistics, facilitating the fulfillment of "Koch's postulates" for begomoviruses. In the absence of seeds and after unsuccessful repeated transformation attempts, we were unable to use $D$. borbonica as a test plant in this study.

Geminiviruses trigger the gene silencing machinery of the host upon virus infection, which enables the infected host plants to recover [14]. Host recovery from geminivirus infection has been reported in several studies, with RNA silencing playing a direct role [15]. One such recovery pattern was seen in tomato plants which recovering from infection with tomato chlorotic mottle virus [16] and pepper plants recovering from infection with pepper golden mosaic virus [17]. Successful symptomatic infection of $N$. benthamiana by $\mathrm{DMV}$ is probably due in part to the hypersusceptible nature of this plant to virus infection, caused by a defective RNAsilencing-mediated host defense. $[18,19]$. In test plants that exhibited the recovery phenotype, DMV was detectable even in uninoculated leaves [20]. Hypersensitive (HR) and necrotic responses are symptomatic manifestations of the plant's host immune system triggered in virus-infected cells [21]. From our infectivity results, it may be concluded that cassava was not susceptible to DMV and that a resistant (or incompatible) host-virus interaction existed whereby HR was triggered upon virus infection and the resultant necrosis prevented subsequent establishment and movement of the virus.

Recombination, mutation and pseudo-recombination are responsible for driving the evolution of begomoviruses [22]. Globally, eight centers of diversification of geminiviruses exist, and East Africa is believed to be a center of diversity for begomoviruses [23]. So far, DMV has not been reported to be an economic threat, and thus is not an immediate concern for crop production, but it can be a potential threat and may cause problems in the future if it recombines with 


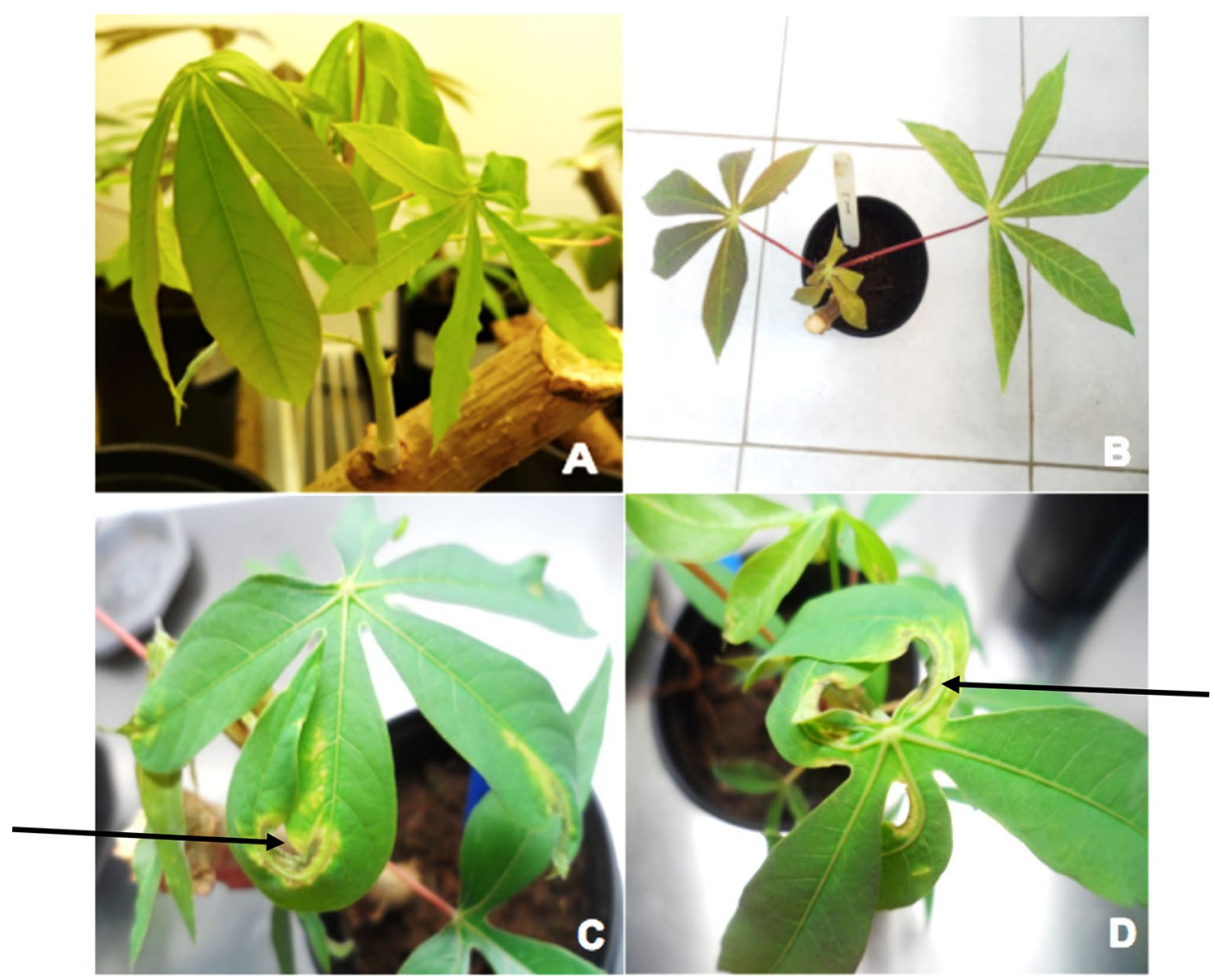

Fig. 5 Hypersensitive response (HR) induced by DMV in cassava test plants. Cassava plants inoculated with concatemeric DNAs exhibited a hypersensitive reaction to the virus on leaves developing immediately after the point of inoculation. The photographs represent

crop-infecting begomoviruses. There is potential for DMV to become pathogenic in a permissive host. The findings of this study suggest that there is resistance in cassava to DMV, which may be the case with many other viruses. However, high virus pressure and frequent occurrence of genomic recombination among begomoviruses may eventually result in resistance breakdown and lead to potentially serious problems to crops in the region. Recombination events have been directly implicated in the emergence of new begomovirus diseases and epidemics in cultivated hosts [24]. The devastating epidemics of cassava mosaic disease (CMD) caused by the Ugandan variant of East African cassava mosaic virus (EACMV-UG) in Uganda and neighboring countries [25], the tomato leaf curl virus (TYLCV) epidemics in the southern, central and northern parts of America, southern Asia, Africa and the Mediterranean basin [26], and the cotton leaf curl virus $(\mathrm{CLCuV})$ epidemics in India and Pakistan [27] were all caused by a complex of begomoviruses including several recombinants.

One of the major obstacles to implementing effective disease surveillance and diagnosis is incomplete knowledge of the identity and level of genetic diversity occurring within populations of begomoviruses within a distinct mock-inoculated test plant controls at approximately $14 \mathrm{dpi}$ (A), and 28 dpi (B). Virus-inoculated plants exhibited spreading of necrosis along the main vein (shown by arrows) and misshaped leaflets 28 dpi $(\mathrm{C}$, and D)

region. Understanding the source(s) of new infections will facilitate the development of appropriate mitigation strategies against specific diseases in affected areas. It is certain that many undescribed begomoviruses are present in nature and are yet to emerge as a threat to crop cultivation in Africa. There is need for more studies to be done to identify other weed-infecting viruses that may present potential dangers to agriculture in the affected regions.

Acknowledgements This study was funded by the Bill \& Melinda Gates Foundation (grant number OPP1052391) through Mikocheni Agricultural Research Institute (MARI), Tanzania. We appreciate the contribution of Samuel Mwaura of Cassava Virus Disease Diagnostics Project for supplying the cassava cuttings.

\section{Compliance with ethical standards}

Conflict of interest The authors declare no conflicts of interest.

Research involving human participants and/or animals No part of this study was performed with human participants or animals by any of the authors.

Informed consent Informed consent was obtained from individual farmers for the samples used in this study. 
Open Access This article is distributed under the terms of the Creative Commons Attribution 4.0 International License (http://creativecommons.org/licenses/by/4.0/), which permits unrestricted use, distribution, and reproduction in any medium, provided you give appropriate credit to the original author(s) and the source, provide a link to the Creative Commons license, and indicate if changes were made.

\section{References}

1. Zerbini FM, Briddon RW, Idris A et al (2017) ICTV virus taxonomy profile: geminiviridae. J Gen Virol 98:131-133

2. Seal SE, VandenBosch F, Jeger MJ (2006) Factors influencing begomovirus evolution and their increasing global significance: implications for sustainable control. CRC Crit Rev Plant Sci 25:23-46

3. Leke WN, Mignouna DB, Brown JK, Kvarnheden A (2015) Begomovirus disease complex: emerging threat to vegetable production systems of West and Central Africa. Agric Food Secur 4:1

4. Anupam V, Malathi VG (2003) Emerging geminivirus problems: a serious threat to crop production. Ann Appl Biol 142:145-164

5. Gutierrez C (2000) DNA replication and cell cycle in plants: learning from geminiviruses. EMBO J 19:792-799

6. Sanderfoot AA, Lazarowitz SG (1995) Cooperation in viral movement: the geminivirus BL1 movement protein interacts with BR1 and redirects it from the nucleus to the cell periphery. Plant Cell 7:1185-1194

7. Barreto SS, Hallwass M, Aquino OM, Inoue-Nagata AK (2013) A study of weeds as potential inoculum sources for a tomato-infecting begomovirus in central Brazil. Phytopathology 103:436-444

8. Tahir M, Amin I, Haider MS et al (2015) Ageratum enation virus - a begomovirus of weeds with the potential to infect crops. Viruses 7:647-665

9. Smith HA, Nagle CA, Evans GA (2014) Densities of eggs and nymphs and percent parasitism of Bemisia tabaci (Hemiptera: Aleyrodidae) on common weeds in west central Florida. Insects 5:860-876

10. Sseruwagi P, Maruthi MN, Colvin J et al (2006) Colonization of non-cassava plant species by cassava whiteflies (Bemisia tabaci) in Uganda. Entomol Exp Appl 119:145-153

11. Silva FN, Lima ATM, Rocha CS et al (2014) Recombination and pseudorecombination driving the evolution of the begomoviruses tomato severe rugose virus (ToSRV) and tomato rugose mosaic virus (ToRMV): two recombinant DNA-A components sharing the same DNA-B. Virol J 11:66

12. Tiendrébéogo F, Lefeuvre P, Hoareau M et al (2012) Evolution of African cassava mosaic virus by recombination between bipartite and monopartite begomoviruses. Virol J 9:67

13. Kyallo M, Sseruwagi P, Skilton RA et al (2017) Deinbollia mosaic virus: a novel begomovirus infecting the sapindaceous weed Deinbollia borbonica in Kenya and Tanzania. Arch Virol 162:1393-1396
14. Vanithatani R, Chellappan P, Fauquet CM (2003) Short interfering RNA-mediated interference of gene expression and viral DNA accumulation in cultured plant cells. Proc Natl Acad Sci USA 100:9632-9636

15. Hanley-Bowdoin L, Bejarano ER, Robertson D, Mansoor S (2013) Geminiviruses: masters at redirecting and reprogramming plant processes. Nat Rev Microbiol 11:777-788

16. Ribeiro SG, Lohuis H, Goldbach R, Prins M (2007) Tomato chlorotic mottle virus is a target of RNA silencing but the presence of specific short interfering RNAs does not guarantee resistance in transgenic plants. J Virol 81:1563-1573

17. Carrillo-Tripp J, Lozoya-Gloria E, Rivera-Bustamante RF (2007) Symptom remission and specific resistance of pepper plants after infection by pepper golden mosaic virus. Phytopathology 97:51-59

18. Yang S, Carter SA, Cole AB et al (2004) A natural variant of a host RNA-dependent RNA polymerase is associated with increased susceptibility to viruses by Nicotiana benthamiana. Proc Natl Acad Sci USA 101:6297-6302

19. Akhtar S, Briddon RW, Mansoor S (2011) Reactions of Nicotiana species to inoculation with monopartite and bipartite begomoviruses. Virol J 8:475

20. Jovel J, Walker M, Sanfaçon H (2007) Recovery of Nicotiana benthamiana plants from a necrotic response induced by a nepovirus is associated with RNA silencing but not with reduced virus titer. J Virol 81:12285-12297

21. Komatsu K, Hashimoto M, Ozeki J et al (2010) Viral-induced systemic necrosis in plants involves both programmed cell death and the inhibition of viral multiplication, which are regulated by independent pathways. Mol Plant Microbe Interact 23:283-293

22. Serfraz S, Amin I, Akhtar KP, Mansoor S (2015) Recombination among begomoviruses on malvaceous plants leads to the evolution of okra enation leaf curl virus in Pakistan. J Phytopathol 163:764-776

23. Ndunguru J, Legg JP, Aveling TAS et al (2005) Molecular biodiversity of cassava begomoviruses in Tanzania: evolution of cassava geminiviruses in Africa and evidence for East Africa being a center of diversity of cassava geminiviruses. Virol J 2:21

24. Pita JS, Fondong VN, Sangare A et al (2001) Recombination, pseudorecombination and synergism of geminiviruses are determinant keys to the epidemic of severe cassava mosaic disease in Uganda. J Gen Virol 82:655-665

25. Sseruwagi P, Rey MEC, Brown JK, Legg JP (2004) The cassava mosaic geminiviruses occurring in Uganda following the 1990s epidemic of severe cassava mosaic disease. Ann Appl Biol 145:113-121

26. Basak J (2016) Tomato yellow leaf curl virus: a serious threat to tomato plants world wide. J Plant Pathol Microbiol 7:1000346

27. Saleem H, Nahid N, Shakir S et al (2016) Diversity, mutation and recombination analysis of cotton leaf curl geminiviruses. PLoS One 11:1-12 